\title{
Calibration of Soil Test Based Balance Fertilizer Doses with FYM for Wheat under High Density Planting System in Midland Alfisols of Chhattisgarh Plateau
}

\author{
Somdas Sahu ${ }^{1}$, G.K. Sharma ${ }^{1 *}$, T. Chandrakar ${ }^{1}$, \\ L.K. Shrivastava ${ }^{2}$ and Karuna Kant Joshi ${ }^{1}$ \\ ${ }^{1}$ Indira Gandhi Krishi Vishwavidyalaya, Saheed Gundadhur College of Agriculture and Research \\ Station, Jagdalpur, Chhattisgarh, India \\ ${ }^{2}$ Indira Gandhi Krishi Vishwavidyalaya, Department of Soil Science and Agricultural Chemistry, \\ College of Agriculture, Raipur, Chhattisgarh, India \\ *Corresponding author
}

\section{A B S T R A C T}

\begin{tabular}{|l|}
\hline Ke y w o r d s \\
Alfisols, Nutrient \\
requirement, Optimum \\
fertilizer doses, Plant \\
uptake, High density \\
wheat, Soil tests, \\
Yield target.
\end{tabular}

\section{Introduction}

Wheat is a most important cereal crop in world and second most important crop in India after rice, which covers 31.19 million hectare area with production of 95.91 million tonnes and productivity of $3075 \mathrm{~kg} \mathrm{ha}^{-1}$ (Anonymous, 2014). In Chhattisgarh, wheat is generally cultivated; during rabi season after harvest of kharif rice, in 1.70 lakh ha area with production of 2.12 lakh tone with 1250 $\mathrm{kg} \mathrm{ha}{ }^{-1}$ productivity, less than half of the national productivity although climatic conditions particularly temperature is becoming favourable for wheat cultivation i.e. cool and long winter in plateau zone of Chhattisgarh (Sharma and Chaudhary, 2014).

The main reasons of low productivity are cultivation of medium to long duration paddy and delayed sowing of wheat after paddy with limited irrigation facilities and inadequate 
technical knowledge of package and practices, including nutrient management. Generally wheat like other cool season crop is seeded early to take maximum period for growth and development toward maturity before the possible heat stress. However early sowing of wheat under rice-wheat system is generally not possible in low and midland situation because of time required for proper seed bed preparation for wheat crop. Late sown wheat suffers more winter injury, which produces fewer tillers and may ripen in lower grain weight and number of grains per plant. In this case farmers generally increases seed rate to counter the ill effects of late sowing. Several workers have reported benefits of high density planting of wheat in terms of yield, nutrient uptake and nutrient use efficiencies under late sown conditions (Hiltbrunner et al., 2007; Drews et al., 2009, Chen et al., 2010).

Fertilizer is one of the costliest inputs in agriculture and the use of right amount of fertilizer is fundamental for farm profitability and environmental protection (Kimetu et al., 2004).

To enhance farm profitability under different soil-climate conditions, it is necessary to have information on optimum doses for crops. Traditionally, to determine optimum fertilizer doses the most appropriate method are to apply fertilizer on the basis of soil test and crop response correlation studies using targeted yield approach to develop relationship between crop yields on the one hand and soil test values and fertilizer inputs on the other (Ramamoorthy et al., 1967).

Theory of formulating optimum fertilizer recommendations for targeted yields was first given by Troug (1960) which was further modified by Ramamoorthy et al., (1967) as "targeted yield model". For achieving a definite yield target of a crop, a definite quantity of nutrients must be applied to the crop and this requirement of nutrients can be calculated by taking into consideration the contribution of native soil available nutrients and applied fertilizer nutrients (Subba Rao and Srivastava, 2001).

Use of organics to improve nutrient status, soil properties, enhance nutrient recovery, productivity of crops and optimum biological activities has been successfully demonstrated in recent literature (Regar and Singh, 2014, Sharma et al., 2015 and Mandal et al., 2016) but information is meagre on soil test based nutrient management in wheat under high density panting system. Such information will be helpful in improving yields and nutrient use efficiencies of wheat simultaneously maintaining and enhancing soil fertility.

\section{Materials and Methods}

The soil test crop response correlation study was conducted at Shaheed Gundadhoor College of Agriculture and Research Station, Jagdalpur, Bastar, Chhattisgarh, India, during the rainy season (kharif) 2016. Bastar is situated between $17^{\circ} 46^{\prime}$ and $20^{\circ} 34^{\prime} \mathrm{N}$ latitude and between $80^{\circ} 15^{\prime}$ and $82^{\circ} 15^{\prime} \mathrm{E}$ longitude with altitude ranging from 550 to $760 \mathrm{~m}$ above mean sea level on the eastern plateau, which is characterized by undulating topography having complex and heterogeneous physiographic settings.

The average normal annual rainfall of the area is about $1440 \mathrm{~mm}$ but its distribution is very erratic. Wheat is the major rabi crop of the Bastar region grown under semi irrigated conditions. The farmers adopt traditional methods of cultivation with very little use of fertilizers and plant protection measures. Alfisols are the most abundant soils in Bastar region, accounted for $45 \%$ of geographical and $50 \%$ of the potentially productive land area. 


\section{Fertility gradient experiment}

Before conducting the main experiment, the fertility-gradient-stabilizing experiment was conducted. The field was divided into three equally long strips $(50 \mathrm{~m} \times 16.66 \mathrm{~m})$ denoted as L0, L1, and L2. The variation in soil fertility with respect to $\mathrm{N}, \mathrm{P}$, and $\mathrm{K}$ nutrients was created by applying 150-100-100 and 300-200-200 kg ha ${ }^{-1}$ of $\mathrm{N}$, phosphorus pentoxide $\left(\mathrm{P}_{2} \mathrm{O}_{5}\right)$ and potassium oxide $\left(\mathrm{K}_{2} \mathrm{O}\right)$ respectively in L1 and L2 strips respectively, keeping the L0 strip as unfertilized (control). The hybrid fodder maize was grown during the previous summer season as an exhaust crop so that the fertilizer applied could interact with soil, plant, and microbes and thus become a part of the soil system. In this way, by growing an exhaust crop, a wide range of soil-test values was created in the fertility strips, which were evaluated in terms of variations in grain yield, nutrient uptake, and soil-test values. The exhaust crop was harvested after 30 days of sowing

\section{STCR experiment}

After harvest of the exhaust crop, the main experiment on high density wheat (variety: GW- 273) was conducted in the subsequent winter season 2016-17 on the site of fertility gradient experiment. Each strip (made in the fertility-gradient-stabilizing experiment in the previous season) was divided into 24 plots ( 21 fertilizer treatments +3 control plots), resulting in 72 plots. Three blocks (A, B, C) comprising 8 treatments were made within a strip randomized with farmyard manure levels. These treatments comprised various selected combinations of levels of nitrogen $(0$, $\left.60,120,180 \mathrm{~kg} \mathrm{~N} \mathrm{ha}^{-1}\right)$, phosphorus $(0,40$, $\left.80,120 \mathrm{~kg} \mathrm{P}_{2} \mathrm{O}_{5} \mathrm{ha}^{-1}\right)$, potassium $(0,40,80$, $\left.120 \mathrm{~kg} \mathrm{~K}_{2} \mathrm{O} \mathrm{ha}^{-1}\right)$, and farmyard manure (0, 5, 10 tons of farmyard manure $\mathrm{ha}^{-1}$ ) and were randomized in each of the three strips. The fertilizer materials used were urea, single superphosphate, and muriate of potash. Full doses of $\mathrm{P}_{2} \mathrm{O}_{5}$ and $\mathrm{K}_{2} \mathrm{O}$ were applied as basal at the time of sowing of the crop. The fertilizer $\mathrm{N}$ was applied in three equal splits, one third as basal, one third as top dressing at 21 days after sowing (DAS), and the remaining one third as top dressing at the flowering stage. Before application of fertilizer, FYM at 0,5 , and 10 ton ha ${ }^{-1}$ as per treatments structure were applied and thoroughly mixed in soil. The crop was sown at a spacing of $15 \mathrm{~cm} \times 5 \mathrm{~cm}$. The soil samples at 0-0.15 m deep were collected from each plot before and after sowing of test crop, dried, passed through a 2-mm sieve, and analyzed for physicochemical characteristics as described by Jackson (1973). The soil available $\mathrm{N}$ was analyzed by alkaline permanganate method (Subbaiah and Asija, 1956), available P by Bray (1948) method, and available $\mathrm{K}$ by the ammonium acetate method (Hanway and Heidal, 1952). The plant sampling was done according to the procedure followed by Witt et al., (1999). In the targeted yield approach for formulating fertilizer recommendations, the basic data

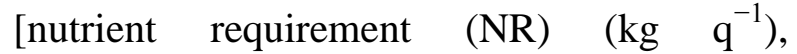
percentage contribution from the soil available nutrients (CS, \%), and the percentage contribution from the applied fertilizer nutrients $(\mathrm{CF}, \%)$ ] were derived and used to calibrate the fertilizer adjustment equations (Velayutham et al., 1985a; Rao and Srivastava, 2000):

$\mathrm{F}\left(\mathrm{kgha}^{-1}\right)=\frac{\mathrm{NR}\left(\mathrm{kg} \mathrm{q}^{-1}\right)}{\mathrm{Cf}} \times \mathrm{Y}\left(\mathrm{q} \mathrm{ha}^{-1}\right)-\frac{\mathrm{CS}}{\mathrm{Cf}} \times s\left(\mathrm{~kg} \mathrm{ha}^{-1}\right)-\frac{\mathrm{CFYM}}{\mathrm{Cf}} \times \mathrm{FYM}\left(\mathrm{tha}^{-1}\right)$

where $\mathrm{F}$ is fertilizer $\left(\mathrm{kg} \mathrm{ha}^{-1}\right)$, NR is nutrient requirement of $\mathrm{N}$ or $\mathrm{P}_{2} \mathrm{O}_{5}$ or $\mathrm{K}_{2} \mathrm{O} \mathrm{kg} \mathrm{q}$ produce, $\mathrm{Cs}$ is percent contribution from soil, $\mathrm{Cf}$ is percent contribution from fertilizer, CFYM is percent contribution from FYM, S is soil-test value for available $\mathrm{N}, \mathrm{P}$, or $\mathrm{K}(\mathrm{kg}$ $\left.\mathrm{ha}^{-1}\right)$, $\mathrm{Y}$ is yield target $\left(\mathrm{q} \mathrm{ha}^{-1}\right)$, and FYM is farmyard manure $\left(\mathrm{t} \mathrm{ha}^{-1}\right)$. A standard regression procedure was used to relate the 
soil test and fertilizer with crop yield response (Draper and Smith, 1998). The nutrient requirement, soil, fertilizer, and farmyard manure efficiencies were derived as discussed by Velayutham et al., (1985b) and Maruthi Sankar (1986).

\section{Results and Discussion}

The experiments were conducted with the basic assumption that fertilizer recommendation would depend on the crop response, in which spatial variability has to be minimized for every independent variable affecting crop yield except for the nutrient in question, although many non-fertility variables (viz., soil texture, soil bulk density, available water content) and other fertility variables would significantly impact the crop yield (Kastens et al., 2003).

As per the approach suggested by Ramamoorthy (1967), variation in soil fertility was deliberately created by adding graded fertilizer doses and maize was sown as exhaust crop during summer season, 2016 so that the added nutrients may naturally transform in to the soil system. Fodder yield of maize in different fertility strips (Table 1) indicated that gradient in fertility level exists. After harvest of fodder maize crop, soil samples were analyzed from each strip. Maize yield and soil test data (Table 1) showed that there were little variations in soil test $\mathrm{N}$ (alkaline $\mathrm{KMnO}_{4}-\mathrm{N}$ ). However, the variations in Bray's $\mathrm{P}$ were quite marked and ammonium acetate extractable- $\mathrm{K}$ did not reflect variations in different fertility strips.

Gradient with respect to $\mathrm{P}$ was observed quite marked, as the nature of $\mathrm{P}$ is immobile and subjected to fix in soil particularly high in alfisols. Phosphorus ions react very quickly with soil constituents to form insoluble compounds depending on the nature of soil, and thus remains in soil. However, there was no gradient created with respect to $\mathrm{N}$ and $\mathrm{K}$ as the nature of $\mathrm{N}$ in soil is very dynamic and its different forms are subjected to losses through leaching volatilization and de-nitrification. The high $\mathrm{K}$ status of the experimental field soil and maintenance of its dynamic equilibrium might be the possible reason for almost the same soil test $\mathrm{K}$ levels in all strips.

\section{Soil available nutrients}

Soil samples from each plot were taken before conducting the main experiments during Rabi season and analyzed for available N, P and K (Table 2). Mean values of available $\mathrm{N}$ ranged from 197.6-257.2 kg. The level of soil $\mathrm{P}$ increased with respect to fertility strips from $\mathrm{L} 0$ to $\mathrm{L} 2$. Average available $\mathrm{P}$ ranged from 10.2- $35.0 \mathrm{~kg} \mathrm{ha}^{-1}$. Similarly, the mean values of available $\mathrm{K}$ status were recorded in the range from $307.4-467.5 \mathrm{~kg} \mathrm{ha}^{-1}$.

The soil test data indicate that available N, P and $\mathrm{K}$ varied with different fertility strips although available $\mathrm{N}$ and $\mathrm{K}$ variations with respect to fertility strip were marginal however, available $\mathrm{P}$ variation in different strips were quite marked and it increased across the fertility strips. Gradient with respect to available $\mathrm{P}$ was observed clearly due to immobile nature of $\mathrm{P}$ and fixed with soil constituents to form insoluble compounds depending on the nature of soil and thus remains in soil.

However, there was no gradient created with respect to $\mathrm{N}$ and $\mathrm{K}$ as the nature of $\mathrm{N}$ in soil is very dynamic and its different forms are subjected to losses through leaching, volatilization and de-nitrification. Average $\mathrm{K}$ status of the experimental field soil was in medium level and maintenance of its dynamic equilibrium might be the possible reason for almost the same mean soil test $\mathrm{K}$ levels in all strips. 


\section{Crop response to added nutrients}

The data in Table 3 showed the range and average values of grain yield of wheat in relation to three fertility strips. The overall wheat grain yield was recorded in the range of 7.9-49.5 $\mathrm{q} \mathrm{ha}^{-1}$ with an average of $33.1 \mathrm{q} \mathrm{ha}^{-1}$. The standard deviation (SD) and coefficient of variation (CV\%) were observed higher in L0 strip and declined under L1 and L2 strip indicating thereby that the yield variations were higher in L0 strip due to soil nutrients variation. The increase in yield with respect to fertility strips may be due to creation of fertility gradient with respect to soil $\mathrm{P}$ from L0 to L2.

Table.1 Fertilizer doses to create fertility gradient and fodder yield of maize in different strips before main complex experiment

\begin{tabular}{|c|c|c|c|c|c|c|c|}
\hline \multirow{2}{*}{$\begin{array}{c}\text { Fertility } \\
\text { Strips }\end{array}$} & \multicolumn{3}{|c|}{ Fertilizer doses $\left(\mathrm{kg} \mathrm{ha}^{-1}\right)$} & \multirow{2}{*}{$\begin{array}{c}\begin{array}{c}\text { Fodder yield } \\
\left(\mathrm{t} \mathrm{ha}^{-1}\right)\end{array} \\
\end{array}$} & \multicolumn{3}{|c|}{ Post-harvest soil test values $\left(\mathrm{kg} \mathrm{ha}^{-1}\right)$} \\
\hline & $\mathbf{N}$ & $\mathbf{P}_{2} \mathbf{O}_{5}$ & $\mathrm{~K}_{2} \mathrm{O}$ & & SN & SP & SK \\
\hline $\mathbf{L}_{0}$ & 0 & 0 & 0 & 8.3 & 217 & 13.3 & 372 \\
\hline $\mathbf{L}_{1}$ & 150 & 100 & 100 & 20.8 & 220 & 17.8 & 390 \\
\hline $\mathbf{L}_{2}$ & 300 & 200 & 200 & 25.6 & 226 & 26.4 & 401 \\
\hline
\end{tabular}

Table.2 Range and mean values of available N, P and K $\left(\mathrm{kg} \mathrm{ha}^{-1}\right)$ before Rabi season, 2016-17 with high density wheat crop

\begin{tabular}{|c|c|c|c|c|c|}
\hline Fertility Strips & Minimum & Maximum & Average & SD & $\mathrm{CV}(\%)$ \\
\hline \multicolumn{6}{|c|}{ Alkaline $\mathrm{KMnO}_{4}-\mathrm{N}\left(\mathrm{kg} \mathrm{ha}^{-1}\right)$} \\
\hline $\mathbf{L}_{0}$ & 200.7 & 234.7 & 212.3 & 10.4 & 4.9 \\
\hline $\mathbf{L}_{1}$ & 197.6 & 233.3 & 216.4 & 40.1 & 18.5 \\
\hline $\mathbf{L}_{2}$ & 200.7 & 257.2 & 222.5 & 44.1 & 19.8 \\
\hline All strips & 197.6 & 257.2 & 217.1 & 12.3 & 5.6 \\
\hline \multicolumn{6}{|c|}{ Bray's-P $\left(\mathrm{kg} \mathrm{ha}^{-1}\right)$} \\
\hline $\mathbf{L}_{0}$ & 10.2 & 17.5 & 14.3 & 2.4 & 16.6 \\
\hline $\mathbf{L}_{1}$ & 12.3 & 23.7 & 18.3 & 4.2 & 22.9 \\
\hline $\mathbf{L}_{2}$ & 14.0 & 35.0 & 25.8 & 6.7 & 25.9 \\
\hline All strips & 10.2 & 35.0 & 19.6 & 6.4 & 32.8 \\
\hline \multicolumn{6}{|c|}{$\mathrm{NH}_{4} \mathrm{OAc}-\mathrm{K}\left(\mathrm{kg} \mathrm{ha}^{-1}\right)$} \\
\hline $\mathbf{L}_{0}$ & 333.2 & 408.5 & 369.6 & 21.6 & 5.8 \\
\hline $\mathbf{L}_{1}$ & 332.2 & 443.3 & 388.9 & 74.1 & 19.0 \\
\hline $\mathbf{L}_{2}$ & 307.4 & 467.5 & 396.9 & 84.4 & 21.3 \\
\hline All strips & 307.4 & 467.5 & 385.5 & 37.8 & 9.8 \\
\hline
\end{tabular}

Table.3 Range and mean of grain yields of high density wheat during Rabi season, 2016-17 in relation to fertility strips

\begin{tabular}{cccccc}
\hline \multirow{2}{*}{ Fertility Strips } & \multicolumn{3}{c}{ Grain yield $\left(\mathbf{q ~ h a}^{-\mathbf{1}}\right)$} & SD & CV \% \\
\cline { 2 - 4 } & Minimum & Maximum & Average & & \\
\hline $\mathbf{L}_{\mathbf{0}}$ & 7.9 & 44.7 & 31.3 & 12.3 & 39.3 \\
$\mathbf{L}_{\mathbf{1}}$ & 9.7 & 46.8 & 33.1 & 12.5 & 37.6 \\
$\mathbf{L}_{\mathbf{2}}$ & 11.9 & 49.5 & 34.0 & 12.4 & 36.4 \\
\hline All strips & 7.9 & 49.5 & 33.1 & 12.0 & 36.3 \\
\hline
\end{tabular}


Table.4 Selected regression model to account for yield variation of high density wheat

\begin{tabular}{clc}
\hline S. No & \multicolumn{1}{c}{ General regression models for high density wheat } & $\mathbf{R}^{2}$ \\
\hline 1 & $\mathrm{y}=14.067+0.178 \mathrm{FN}$ & 0.910 \\
2 & $\mathrm{y}=12.553+0.24 \mathrm{FN}-0.0003 \mathrm{FN}^{2}$ & 0.921 \\
3 & $\mathrm{y}=19.166+0.2105 \mathrm{FP}$ & 0.509 \\
4 & $\mathrm{y}=18.293+0.2629 \mathrm{FP}-0.0004 \mathrm{FP}^{2}$ & 0.512 \\
5 & $y=23.477+0.1577 \mathrm{FK}$ & 0.269 \\
6 & $y=21.72+0.2591 \mathrm{FK}-0.0009 \mathrm{FK}^{2}$ & 0.281 \\
7 & $y=31.682+0.3038 \mathrm{FYM}$ & 0.011 \\
\hline \multicolumn{1}{c}{ Nutrient substitution models for high density wheat } \\
\hline 8 & $\mathrm{Y}=12.160+0.152 \mathrm{FN}+0.070 \mathrm{FP}$ & 0.948 \\
9 & $2 \mathrm{Y}=11.948+0.151 \mathrm{FN}+0.066 \mathrm{FP}+0.010 \mathrm{FK}$ & 0.949 \\
10 & $\mathrm{Y}=10.429+0.151 \mathrm{FN}+0.066 \mathrm{FP}+0.010 \mathrm{FK}+0.304 \mathrm{FYM}$ & 0.960 \\
11 & $\mathrm{Y}=12.548+0.178 \mathrm{FN}+0.304 \mathrm{FYM}$ & 0.922 \\
12 & $\mathrm{Y}=0.495-0.064 \mathrm{SN}+0.175 \mathrm{FN}$ & 0.914 \\
13 & $\mathrm{Y}=13.905+0.339 \mathrm{SP}+0.190 \mathrm{FP}$ & 0.536 \\
\hline
\end{tabular}

Where, FN, FP and FK are fertilizer $\mathrm{N}_{1} \mathrm{P}_{2} \mathrm{O}_{5}$, and $\mathrm{K}_{2} \mathrm{O}\left(\mathrm{Kg} \mathrm{ha}^{-1}\right)$ respectively. FYM is Farm Yard Manure ( $\left.\mathrm{t} \mathrm{ha}^{-1}\right)$. $\mathrm{SN}, \mathrm{SP}$ and $\mathrm{SK}$ are soil test values for available $\mathrm{N}, \mathrm{P}$ and $\mathrm{K}\left(\mathrm{kg} \mathrm{ha}^{-1}\right)$. Y is crop yield.

Table.5 Relation of high density wheat yield (Y) with total nutrient uptake (U)

\begin{tabular}{ccccccc}
\hline Nutrient & $\mathbf{Y}=\mathbf{b 1} \mathbf{U}$ & $\mathbf{R}^{2}$ & $\begin{array}{c}\text { NR } \\
\left(\mathbf{k g ~ q}^{\mathbf{- 1}}\right)\end{array}$ & $\begin{array}{c}\text { Fertilizer } \\
\text { Efficiency (\%) } \mathbf{E}_{\mathbf{f}}\end{array}$ & $\begin{array}{c}\text { Soil Test } \\
\text { Efficiency }(\boldsymbol{\%}) \mathbf{E}_{\mathbf{s}}\end{array}$ & $\begin{array}{c}\text { FYM }^{*} \text { Efficiency } \\
(\boldsymbol{\%}) \mathbf{E}_{\mathbf{F Y M}}\end{array}$ \\
\hline $\mathrm{N}$ & $\mathrm{y}=0.495 \mathrm{UN}$ & 0.96 & 2.00 & 34.35 & 13.08 & 13.69 \\
$\mathrm{P}$ & $\mathrm{y}=1.867 \mathrm{UP}$ & 0.78 & 0.54 & 22.01 & $\mathbf{6 5 . 0 2}$ & $\mathbf{5 . 6 0}$ \\
$\mathrm{K}$ & $\mathrm{y}=0.527 \mathrm{UK}$ & 0.92 & 1.91 & 72.05 & 7.98 & 7.96 \\
\hline
\end{tabular}

*Nutrient content in FYM: $0.3 \%$ N, $0.30 \% \mathrm{P}$ and $0.8 \% \mathrm{~K}$

Table.6 Fertilizer adjustment equations

\begin{tabular}{ll}
\hline 1 & $\mathrm{FN}=5.82 \mathrm{Y}-0.38 \mathrm{SN}-0.40 \mathrm{FYM}$ \\
2 & $\mathrm{FP}=2.48 \mathrm{Y}-2.95 \mathrm{SP}-0.25 \mathrm{FYM}$ \\
3 & $\mathrm{FK}=2.65 \mathrm{Y}-0.11 \mathrm{SK}-0.11 \mathrm{FYM}$ \\
\hline
\end{tabular}

Where, FN, FP and FK are fertilizer $\mathrm{N} \mathrm{P}_{2} \mathrm{O}_{5}$ and $\mathrm{K}_{2} \mathrm{O}\left(\mathrm{Kg} \mathrm{ha}^{-1}\right)$ respectively. FYM is Farm Yard Manure (t ha $\left.{ }^{-1}\right)$. $\mathrm{SN}, \mathrm{SP}$ and SK are soil test values for available $\mathrm{N}, \mathrm{P}$ and $\mathrm{K}\left(\mathrm{kg} \mathrm{ha}^{-1}\right)$. Y is grain yield in $\mathrm{q} \mathrm{ha}^{-1}$.

Table.7 Ready reckoner for soil test based fertilizer $\mathrm{N}, \mathrm{P}_{2} \mathrm{O}_{5}$ and $\mathrm{K}_{2} \mathrm{O}$ recommendation for high density wheat (GW-273) in alfisols with 5 tonnes of FYM

\begin{tabular}{|c|c|c|c|c|c|c|c|c|c|c|c|}
\hline \multirow{2}{*}{\multicolumn{3}{|c|}{ Soil Test values (kg/ha) }} & \multicolumn{9}{|c|}{ Yield Target of Wheat (q/ha) } \\
\hline & & & \multicolumn{3}{|c|}{20} & \multicolumn{3}{|c|}{30} & \multicolumn{3}{|c|}{40} \\
\hline $\mathbf{N}$ & $\mathbf{P}$ & $\mathbf{K}$ & FN & FP & FK & FN & FP & FK & FN & FP & FK \\
\hline 150 & 4 & 200 & 51 & 34 & 25 & 109 & 59 & 52 & 168 & 83 & 78 \\
\hline 175 & 6 & 225 & 42 & 28 & 22 & 100 & 53 & 49 & 158 & 77 & 75 \\
\hline 200 & 8 & 250 & 32 & 22 & 20 & 90 & 47 & 46 & 149 & 72 & 73 \\
\hline 225 & 10 & 275 & 23 & 16 & 17 & 81 & 41 & 43 & 139 & 66 & 70 \\
\hline 250 & 12 & 300 & 13 & 10 & 14 & 71 & 35 & 41 & 130 & 60 & 67 \\
\hline 275 & 14 & 325 & 4 & 4 & 11 & 62 & 29 & 38 & 120 & 54 & 64 \\
\hline 300 & 16 & 350 & 0 & 0 & 9 & 52 & 23 & 35 & 111 & 48 & 62 \\
\hline 325 & 18 & 375 & 0 & 0 & 6 & 43 & 17 & 32 & 101 & 42 & 59 \\
\hline
\end{tabular}



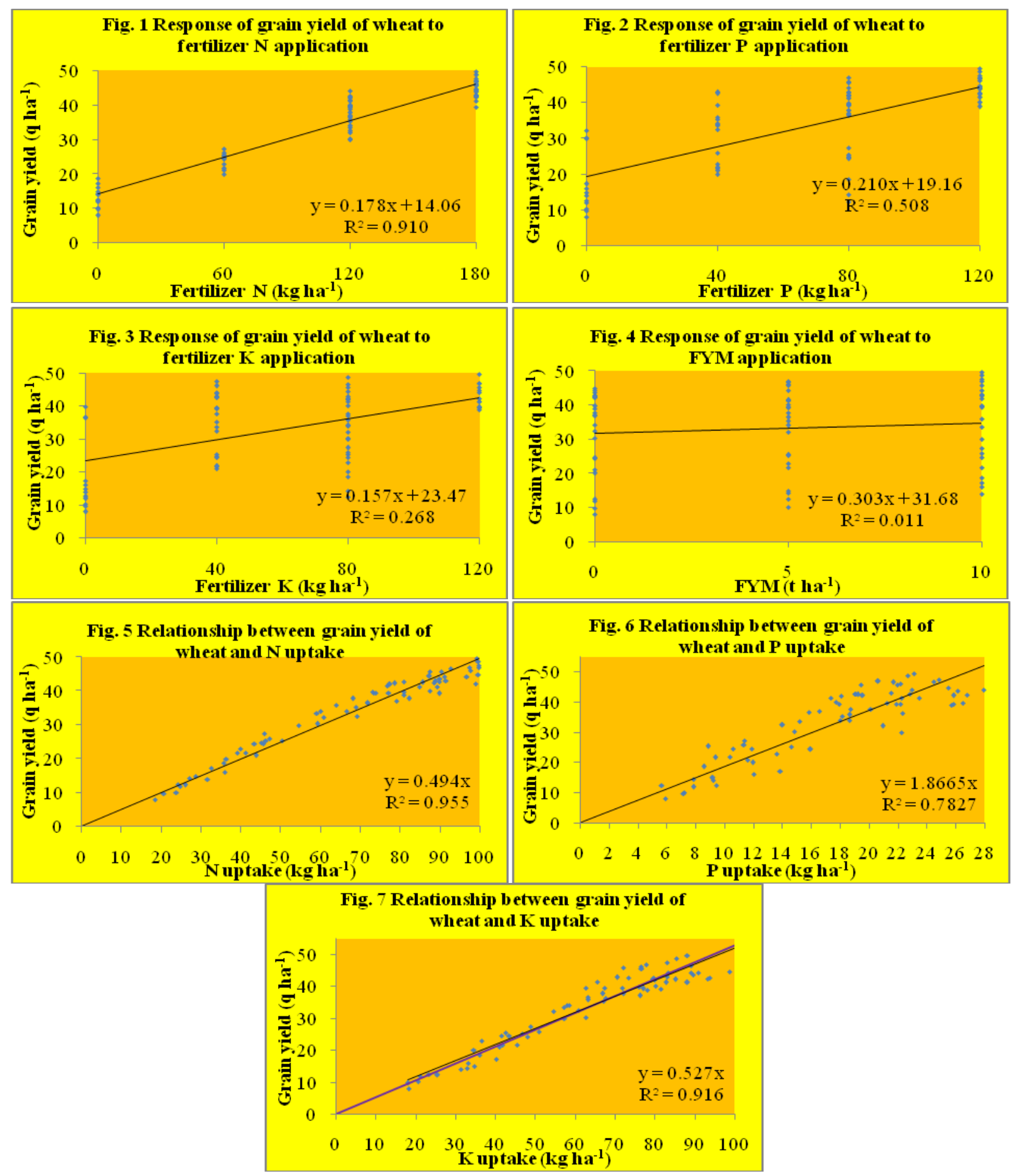

The crop responses to fertilizer N, P, K and FYM have been depicted in Figure 1 to 4 which showed good crop response to the fertilizer $\mathrm{N}$ and $\mathrm{P}$ application whereas response to $\mathrm{K}$ application was less consistent. Crop response to FYM application was not quite marked as shown in Figure 4. The relation of grain yield of wheat with different plant nutrients as independent variables were derived by regression analysis to evaluate the yield variations due to various nutrients (Table 4). The larger proportion of variation in grain yields was accounted for by $\mathrm{N}$ alone. Higher crop response to $\mathrm{N}$ was attributed to 
the high $\mathrm{N}$ requirement and being mobile nature of this element, it is easily accessible to the plants in the root system sorption zone (Ramamoorthy et al., 1967). Fertilizer $\mathrm{P}_{2} \mathrm{O}_{5}$ and $\mathrm{K}_{2} \mathrm{O}$ were the next to explain the rest of variations. The $\mathrm{P}$ ions react very quickly with soil constituents to form insoluble compounds and are thus rendered immobile in the soil. Furthermore, the requirement of $\mathrm{P}$ nutrient in wheat was lower than $\mathrm{N}$ (Table 7). The yield variation due to FYM application was also accounted very poor correlation. However, $94.8 \%$ of the yield variations were estimated due to fertilizer $\mathrm{N}$ and $\mathrm{P}$ only as reflected in the equation given in Table 4. Curvilinear relation of fertilizer $\mathrm{N}$ and $\mathrm{P}$ did not reflect on yield variations.

\section{Relationship between yield and nutrient uptake}

The yield of high density wheat crop was showed the close association with total N, P and $\mathrm{K}$ uptake (Table 5). This relation was used to estimate the nutrient requirement for high density wheat (Table 5). The nutrient requirement (NR) is defined as the amount of nutrient required to produce per unit amount of yield. The nutrient requirement can be given by the regression coefficient $\left(b_{1}\right)$ of yield $(\mathrm{Y})$ and total nutrient uptake (U).

$\mathrm{Y}=\mathrm{b}_{1} \mathrm{U}$ or $\mathrm{U}=1 / \mathrm{b}_{1} * \mathrm{Y}$

Where, $1 / b_{1}$ gives the NR.

The amount of nutrients absorbed by the crop decides a definite amount of biomass production. Nutrient requirement for high density wheat crops have been estimated based on conventional and regression methods which are almost similar values and are shown in the Table 7 and depicted graphically in Figures 5 to 7 showing a close association between crop yields and nutrient uptake with almost a linear relationship. The amount of nutrient required to produce one quintal of high density wheat grain was found to be $2.00 \mathrm{~kg} \mathrm{~N}, 0.54 \mathrm{~kg} \mathrm{P}$ and $1.91 \mathrm{~kg} \mathrm{~K}$. The nutrient requirement is also estimated by the conventional method as given below:

NR $\left(\mathrm{kg} \mathrm{q}^{-1}\right)=\frac{\text { Total Nutrient Uptake }\left(\mathrm{kg} \mathrm{ha}^{-1}\right)}{\text { Grain Yield }\left(\mathrm{kg} \mathrm{ha}^{-1}\right)}$

This parameter gives better results with the regression method which is being followed in present study. Several workers have reported the nutrient requirement of different crops at various places. Ramamoorthy et al., (1967) reported for wheat crop which required $2.5 \mathrm{~kg}$ $\mathrm{N}, 0.8 \mathrm{~kg} \mathrm{P}_{2} \mathrm{O}_{5}$ and $1.0 \mathrm{~kg} \mathrm{~K}_{2} \mathrm{O}$ for one quintal of grain production.

Ahmed and Reddy (2002) reported that the nutrient requirement $\left(\mathrm{kg} \mathrm{q}^{-1}\right)$ of $\mathrm{N}, \mathrm{P}_{2} \mathrm{O}_{5}$ and $\mathrm{K}_{2} \mathrm{O}$ were found to be $1.88,1.09$ and 2.79 , respectively for producing one quintal of rice yield. Gautam et al., (2006) reported that the nutrient requirement $\left(\mathrm{kg} \mathrm{q}^{-1}\right)$ of $\mathrm{N}, \mathrm{P}_{2} \mathrm{O}_{5}$ and $\mathrm{K}_{2} \mathrm{O}$ were found to be $1.78,0.37$ and 2.11 , respectively for producing one quintal of rice yield. Regar and Singh (2014) reported that the nutrient requirements $\left(\mathrm{kg} \mathrm{q}^{-1}\right)$ of $\mathrm{N}, \mathrm{P}_{2} \mathrm{O}_{5}$ and $\mathrm{K}_{2} \mathrm{O}$ for producing one quintal of rice yield in Inceptisols were found to be 2.56, 0.56 and 2.21 , respectively.

\section{Efficiencies of fertilizer, soil test and FYM}

The efficiencies of fertilizer, soil test and FYM were estimated by using the conventional methods with the help of software developed by AICRP on STCR, Indian Institute of Soil Science, Bhopal (MP). The fertilizer efficiencies of $\mathrm{N}, \mathrm{P}$ and $\mathrm{K}$ for high density wheat crop were estimated as (Table 5) 34.35, 22.01 and 72.05 per cent, respectively. The efficiencies of soil test for high density wheat was recorded as $13.08 \%$ $\mathrm{N}, 65.02 \% \mathrm{P}$ and $7.98 \% \mathrm{~K}$. The efficiencies of organic source (FYM) were observed as 
13.69, 5.60, and 7.96 per cent $\mathrm{N}, \mathrm{P}$ and $\mathrm{K}$ for high density wheat crop. The chemical analyses of organics were recorded for NPK @ 0.3: 0.3:0.8 percent, respectively.

It is well known that approximate $2 / 3^{\text {rd }}$ of the applied fertilizer $\mathrm{N}$ lost through leaching, volatilization, de-nitrification and by run-off. Similarly, a large fraction of applied fertilizer $\mathrm{P}$ is fixed in soil by reacting with dominant cations present in the soil like $\mathrm{Fe}, \mathrm{Mn}, \mathrm{Ca}, \mathrm{Mg}$ etc. High efficiency of applied fertilizer $\mathrm{K}$ observed seems to be due to higher uptake of this nutrient as luxury consumption. Soil test efficiencies for $\mathrm{N}$ and $\mathrm{K}$ were recorded less than fertilizer sources and reverse trend was seen in case of soil test P. Ramamoorthy et al., (1967) reported the efficiency of soil N, P and $\mathrm{K}$ were 37,14 and 44.0 per cent, respectively and the efficiency of fertilizer $\mathrm{N}$, $\mathrm{P}$ and $\mathrm{K}$ were 34,41 and 36 per cent, respectively. Similarly Gautam et al., (2006) reported that the per cent contribution to rice from soil was 31.09, 28.39 and 37.21; from applied farmyard manure 30.01, 9.13 and 54.74 and from fertilizer 31.63, 40.50 and 180.81 for N, P, and K respectively. Regar and Singh (2014) reported that the percent nutrient contribution from soil, fertilizer and FYM in an Inceptisols were found to be $26.35,51.17$ and 26.14; 54.03, 36.35 and 75.68; and 18.59, 3.10 and 8.56 for nitrogen, phosphorus and potassium, respectively for rice yield in Inceptisols of Utter Pradesh.

\section{Estimation of fertilizer adjustment equations}

Based on the basic parameters viz. nutrient requirement, efficiencies of fertilizer, soil test and organic source (FYM), fertilizer adjustment equations were evolved for high density wheat crop to achieve a definite yield goal. The following equations (Table 6) were evolved for high density wheat for fertilizer $\mathrm{N}, \mathrm{P}_{2} \mathrm{O}_{5}$ and $\mathrm{K}_{2} \mathrm{O}$.

\section{Ready reckoners for fertilizer doses to high density wheat}

The ready reckoners for high density wheat with the use of 5 tonnes of FYM are shown in Table 7. The application of chemical fertilizer with FYM in integrated manner has beneficial effect by several ways in terms of soil fertility and physical properties improvement and higher fertilizer use efficiencies. It is further evident that the fertilizer requirements decreased with increase in soil test values. Therefore, a slightly lower yield target may be considered for a poor resource farmers to obtain maximum profit per unit cost spent on fertilizer, whereas, a higher yield target for a resourceful farmers who are interested for maximum potential production per unit area. Hence, for maintaining soil fertility, it is necessary to choose appropriate yield targets and fertilizer use practices that achieve the twin objectives of high yield and maintenance of soil fertility.

\section{References}

Ahmed, S.R. and P.V.K. Reddy, 2002. Optimizing fertilizer doses for rice in alluvial soils through chemical fertilizers, farm yard manure and green manure using soil test values. Agropedology 12: 133-140.

Anonymous. 2014. Agricultural Statistics at a Glance 2014. Directorate of Economics and Statistics, Department of Agriculture and Cooperation, Ministry of Agriculture, Government of India.

Bray, R.H. 1948. Requirements for successful soil test. Soil Science 66: 83-89.

Chen, S., X. Zhang, H. Sun, T. Ren and Y. Wang. 2010. Effects of winter wheat row spacing on evapotranpsiration, grain yield and water use efficiency. Agricultural Water Management 97: 1126-1132.

Draper, N. R., and H. Smith. 1998. Applied 
regression analysis. New York: Wiley.

Drews, S., D. Neuhoff and U. Kopke. 2009. Weed suppression ability of three winter wheat varieties at different row spacing under organic farming conditions. Weed Research 49: 526-533.

Gautam, P., A. Srivastava, S. Singh and A.K Saxena. 2006. Soil test crop response based integrated plant nutrition system for rice in tarai region of Uttarakhand. Department of Soil Science, College of Agriculture, G. B. Pant University of Agriculture and Technology, Pantnagar263145 (U.S. Nagar, Uttarakhand) S.G.R.R. (P.G.) College, Dehradun, Uttarakhand.

Hanway, J.J., H. Heidal. 1952. Soil analysis methods as used in Iowa State College. Agriculture Bulletin 57: 1-13.

Hiltbrunner, J., B. Streit and M. Liedgens. 2007. Are seeding densities an opportunity to increase grain yield of winter wheat in a living mulch of white clover? Field Crop Res. 102: 163-171.

Jackson, M.L. 1973. Soil Chemical analysis. Prentice-Hall of India Pvt. Ltd., New Delhi.

Kastens, T. L., J. Schmidt and K. C. Dhuyvetter. 2003. Yield models implied by traditional fertilizer recommendations and a framework for including nontraditional information. Soil Science Society of America Journal 67: 351364.

Kimetu, M., D.N. Mugendi, C.A. Palm, P.K. Mutuo, CN. Gachengo, S. Nandwa and B. Kungu. 2004. African network on soil biology and fertility pp. 207-224.

Mandal, Rakesh, G.K. Sharma, V.N. Mishra, S.K. Patil, L.K. Srivastava and D.S. Thakur. $2016 . \quad$ Fertilizer recommendations based on targeted yield concept involving INM for hybrid maize in rainfed midlands of Bastar. Green Farming 7: 69-73.

Maruthi Sankar, G. R. 1986. On screening of regression models for selection of optimal variable subsets. Journal of Indian Society of Agricultural Statistics 38:161-168.

Ramamoorthy, B., R.L. Narasimhan and R.S. Dinesh. 1967. Fertilizer application for specific yield targets of Sonara-64. Indian Farming 17: 43-45.

Rao, S., and S. Srivastava. 2000. Soil test based fertilizer use-A must for sustainable agriculture. Fertilizer News 45:25-38.

Regar, K.L. and Y.V. Singh. 2014. Fertilizer recommendation based on soil testing for the targeted yield of rice in eastern plain zone of Utter Pradesh. The Bioscane 2: 531-534.

Sharma, G.K. and J.L. Chaudhary. 2014. Time trends in temperature of Bastar plateau agro-climatic zone of Chhattisgarh. Mausam 65: 29-36.

Sharma, G.K., V.N. Mishra, G.R. Maruti Sankar, S.K. Patil, L.K. Srivastava, D.S. Thakur, and Ch. Srinivasa Rao, 2015. Soil Test based Optimum Fertilizer Doses for attaining Yield Targets of Rice under Midland Alfisols of Eastern India, Communications in Soil Science and Plant Analysis, 46 (17): 2177-2190.

Subba Rao, A. and S. Srivastava. 2001. Soil test based fertilizer recommendations for targeted yields of crops. Proceedings of the National Seminar on Soil Testing for Balanced and Integrated Use of Fertilizers and Manures. Indian Institute of Soil Science, Bhopal 326.

Subbiah, B.V. and G.L. Asija. 1956. A rapid procedure the estimation of available nitrogen in soils. Current Science 25: 259-260.

Truog, E. 1960. Fifty years of soil testing. Transactions of Seventh International Congress of Soil Science 3:46-53.

Velayutham, M., K. C. K. Reddy and G. R. Maruthi Sankar. 1985a. Soil test crop response research work in India for 
fertilizer recommendation. In Proceedings of International Symposium on Soil Test Crop Response Correlation Studies, Commission IV of ISSS, BARC and SSSB, Dhaka, Bangladesh, 662-644.

Velayutham, M., K. C. K. Reddy and G. R. Maruthi Sankar. 1985b. All India Coordinated Research Project on soil test crop response correlation and its impact on agricultural production. Indian Journal of Fertilizers 30:81-95.

Witt, C., A. Dobermann, S. Abdulrachman, H. C. Gines, G. H. Wang, R. Nagarajan, S. Satawathananont, T. T. Son, P. S. Tan, and L. V. Tiem. 1999. Internal nutrient efficiencies of irrigated lowland rice in tropical and subtropical Asia. Field Crops Research 63:113-138.

\section{How to cite this article:}

Somdas Sahu, G.K. Sharma, T. Chandrakar, L.K. Shrivastava and Karuna Kant Joshi. 2017. Calibration of Soil Test Based Balance Fertilizer Doses with FYM for Wheat under High Density Planting System in Midland Alfisols of Chhattisgarh Plateau. Int.J.Curr.Microbiol.App.Sci. 6(12): 3733-3743. doi: https://doi.org/10.20546/ijcmas.2017.612.430 